\title{
A comparison of water application uniformity for drip irrigation system above and below soil surface at various soil depths and scheduling techniques in arid region
}

\author{
H. M. Al-Ghobari \\ Agricultural Engineering Department, \\ College of Food and Agricultural Sciences, \\ King Saud University, Saudi Arabia
}

\begin{abstract}
The uniformity of water application and its stability, however, are still a matter of controversy and deserve more investigation. An experiment was conducted to evaluate the surface and subsurface water application uniformity for drip irrigation system using three irrigation scheduling techniques under field conditions and to quantify uniformity of soil water content on the soil surface and below soil surface. In this study an evaluation of uniformity of surface drip irrigation system used to irrigate a tomato crop in Riyadh, Saudi Arabia. Three irrigation scheduling techniques were used in the field to irrigate tomato crop. The uniformity of water application from emitters and subsurface water contents below the soil surface after 24 hours from irrigation was determined at different distances and depths from the emitter in parallel and perpendicular directions to the drip line.

Field results showed evidence the importance of redistribution of the applied water. The values of surface water uniformity from emitters were higher by approximately $13 \%$ than the subsurface uniformity below soil ground after 24 hours from irrigation. Also, the values of coefficients of subsurface uniformity varied in the lower soil layers than in the upper layers for all irrigation scheduling techniques. An experimental relationship between the uniformity coefficients of surface and subsurface was derived under arid region conditions.
\end{abstract}

Keywords: drip irrigation, water redistribution, uniformity, scheduling techniques, below and above soil surface. 


\section{Introduction}

In the arid and semi-arid areas, drip irrigation is frequently used to reach the maximum water use efficiency (Acar et al. [1] and Fabeiro et al. [2]). Drip irrigation (DI) has been used in horticultural operations since the middle of the 20th century (Hillel [3]) and conventional drip irrigation is considered one of the most efficient irrigation systems. Drip irrigation has the potential to use scarce water resources most efficiently to produce vegetables (Locascio [4]). However, DI is an irrigation system whereby water is supplied under low pressure directly treating only to the plant roots (Nautiyal et al. [5]). DI are the most effective way to save water by using water more efficiently to increase crop yields and improve the uniformity of irrigation (Al-Omran et al. [6], Schwankl and Hanson [7], and Zotarelli et al. [8]).

\subsection{Water uniformity and distribution patterns:}

In order to achieve this, the uniformity with which the irrigation system applies water will have to be high. The distribution uniformity of a system has an effect on the system's application efficiency and on the crop yield (Letey et al. [9], Solomon [10], Letey [11] and Solomon [12]). Irrigation systems with poor distribution uniformity experience reduced yields due to water stress and/or water logging (Solomon [13] and Clemmens and Solomon [14]). Poor distribution uniformity also has increased financial and environmental costs. Nutrients can be leached out of the soil due to excess water being applied to overcome poor irrigation uniformity. This will increase fertilizer costs and pumping costs, and may have environmental impacts if the excess runoff and deep percolation are contaminated with nutrients (Solomon [15]). The distribution uniformity of an irrigation system depends both on the system characteristics and on managerial decisions (Pereira [16]). Camp et al. [17] reported that the uniformity of subsurface drip irrigation systems generally would be slightly lower than that of surface drip irrigation systems. If the water and fertilizer are to be applied together, it is crucial to evaluate emitter discharge uniformity and system performance (Camp et al. [18]). Nakayama and Bucks [19] evaluated and compared sprinkler and drip irrigation systems based on the parameters of uniformity coefficient. The emitters in a drip irrigation system provide a point source for water, which infiltrates directly into the soil at the point of emission. Any lateral spreading of the wetted area on the soil surface is due to forces within the soil matrix, rather than forces imparted by the emitter (Karmeli et al. [20]). Therefore, in designing drip irrigation systems it is important to have an assessment of water distribution pattern in the soil profile, because it depends on the discharge rate of the emitter and on the soil characteristics.

There are several coefficients of uniformity that are used to describe the uniformity of irrigation systems. Uniformity of water application in microirrigation depends on system uniformity and spatial uniformity in the field 
(Wu et al. [21]). The system uniformity is affected by system design factors such as lateral diameter and emitter spacing (Wu et al. [22]) and manufacturing variation (Bralts et al. [23]). It is also considered to include emitter clogging (Bralts et al. [24]). In addition to system design factors noted above, it includes variation due to field topography and soil hydraulic properties (Burt and Styles [25] and Burt et al. [26]). The causes of non-uniformity include unequal drainage and unequal application rates (Burt [27]). Overall, minimizing nonuniformity of the drip system requires: a design which considers the topography of the field and periodic checking of the system (Clark et al. [28]) and irrigation scheduling (volume and frequency) Burt et al. [26]. Greater irrigation uniformity can be achieved by using pressure-compensating emitters in surface drip system (Schwankl and Hanson [29]).

Most researchers have concluded that there were differences in uniformity index values above and below the soil surface. However, the effect of redistribution within the soil profile is very dependent on the spatial distance between emitters and above-average and below-average application of irrigation water. Thus, the uniformity of application under irrigation systems may be improved considerably if redistribution within the soil profile is taken into consideration.

The concern of the irrigation system designer is mostly associated with achieving uniformity of water applied from the emitters above the soil surface rather than obtaining a uniform wetting of the root zone or uniformity of water uptake by crop. However, the yield response of the crop is affected by the water within its root zone and therefore, the distribution of water within the soil is more important than its distribution from emitters or above soil surface. Thus, the surface uniformity coefficient may not be an appropriate reflector of the actual water distribution below the soil surface. Davis [30] and Li and Kawano [31] raised the importance of the water redistribution inside the soil profile and stated that the evaluation of water distribution above the soil surface is not a good indicator of crop yield. Also, many investigators (Hart [32], Thooyamani et al. [33] and Al-Ghobari [34]) discussed the uniformity above and below soil soil surface for different irrigation systems and concluded that there was a difference between the water uniformity above and below soil surface.

The above discussion concerning the prediction of uniformity below the soil surface strongly suggests that the current approach to drip system design has limitations. Therefore, there is a need to establish more appropriate design method which takes account of the water applied was distributed in the soil profile after some time of irrigation, and finding a relationship between uniformity of the water above and below soil surface.

The aim of this study was to evaluate the uniformity above and below the soil surface of water application in DI systems under field conditions at various soil surface depths and scheduling techniques in arid region, and to find a relationship between the coefficients of uniformity for the drip irrigation systems above and below soil surface. 


\section{Materials and methods}

The experiments were conducted on October, 2011 at the experimental farm of the College of Food and Agriculture Sciences, King Saud University, Riyadh, at $24^{\circ} 43^{\prime} \mathrm{N}$ latitude, $46^{\circ} 43^{\prime} \mathrm{E}$ longitude and $635 \mathrm{~m}$ altitude. The experimental site was irrigated by a drip irrigation system. The field was further divided into three plots (Fig. 1(a)). Before the start of the experiment, intact soil cores were collected from different locations in the field to determine soil physical properties including soil mechanical analysis. Locations were selected to represent the dominant soil conditions in the field. Three soil samples were taken from each plot at four different depths $(0-20,20-30$ and 30-60 cm) to determine soil texture. The soil type in the plot area was loamy sand $(85.9 \%$ sand, $6 \%$ silt and $8.1 \%$ clay).

Drip irrigation system was installed for each plot as shown in Fig. 1(a). Buffer distances of approximately $3 \mathrm{~m}$ separated the plots to reduce environmental influences between them. Drip system (DI) was equipped with controllers to control the pressure and flow meter to quantify the water added in each irrigation event. Each plot was approximately $4.5 \mathrm{~m}$ wide and $7 \mathrm{~m}$ long and had 5 rows of drip lines spaced $0.9 \mathrm{~m}$ apart running from west to east. Tomato plants were spaced $0.50 \mathrm{~m}$ apart in each row, the 5 drip lines in each plot were connected to a common sub-main irrigation line at the inlet side of the plot and a common flush line and flush valve at the distal end of the plot. The DI system consisted of $16 \mathrm{~mm}$ inside diameter (I.D.) thin-wall drip lines with welded-on emitters (GR, $50 \mathrm{~cm}$ dripper spacing) with a nominal emitter discharge of $4 \mathrm{~L} / \mathrm{h}$ at a design pressure of $200 \mathrm{kPa}$. Drip lines were placed on the soil surface in plots 1, 2 and 3 (Fig. 1(a)). Irrigation amounts were metered separately in each plot using commercial municipal-grade flow accumulators. The irrigation time varied between treatments because of the three different methods of irrigation scheduling used. The hydraulic aspects of the design for drip system aimed to obtain uniform application of irrigation water.
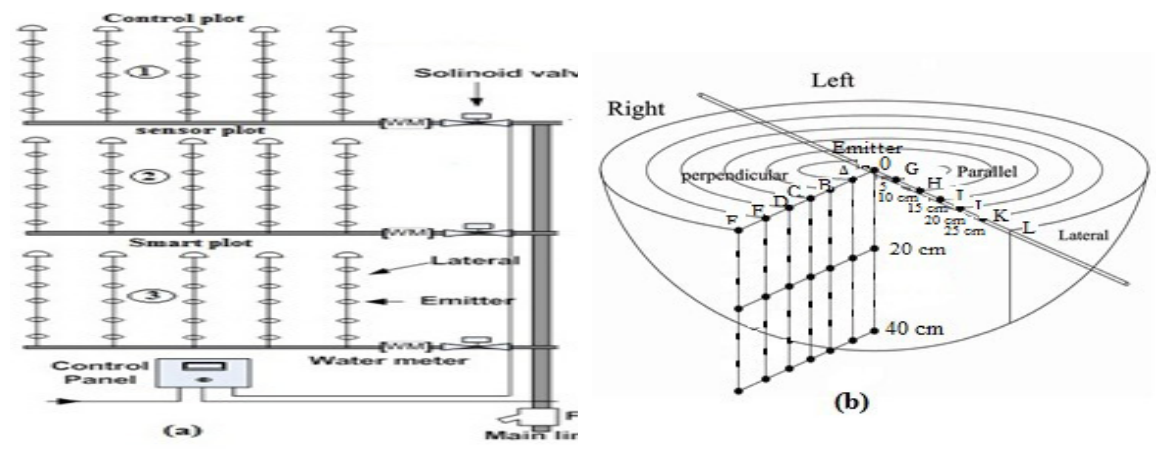

Figure 1: Field experimental layout (a) and diagram showing locations and depths of soil samplings for moisture contents parallel and perpendicular to the direction of drip line (b). 
Three methods of irrigation scheduling were used to determine both the timing and amount of water to be applied to a tomato crop by irrigation system. The irrigation scheduling in plot 1 was controlled by smart controllers which have the ability to add water to the crop when it was needed based on controlled evapotranspiration and weather data. Plot 2 was controlled by automatic watermark soil moisture sensors, and plot 3 was manually irrigated based on weather data collected from an automatic weather station installed at the experimental site and Penman-Montieth equation was used to calculate evapotranspiration (ET).

Drip system was evaluated in the field according to the methodology of ASABE Standard, S346.1 [35]. Evaluation tests were conducted for drip irrigation system by checking values of the Uniformity coefficients under operating field conditions. Also, determination of the uniformity of water redistribution in the soil profile under drip irrigation system, in parallel and perpendicular directions to the drip line, used the gravimetric method to calculate the coefficient of uniformity developed by Christiansen [36]. Soil gravimetric moisture contents were measured at three soil depths $(0,20$ and $40 \mathrm{~cm})$ and at different distances from emitter $(10,15,20$ and $25 \mathrm{~cm}$ in parallel and perpendicular directions to the drip line as shown in Fig. 1(b). The soil water contents were measured 24 hours after water application ceased. The evaluation tests were carried out four times starting from the beginning until the mid of season.

\subsection{Uniformity parameter calculations}

The evaluations of water application uniformity in this study were calculated with 2 methods. First, the uniformity of water applied from the drip irrigation system using discharge measurement data from emitters and the following equations were used to evaluate the drip system. The following equations were by Karmeli and Keller [37] cited by Clemmens and Solomon [38] and employed to compute uniformity Parameters of the drip system. These two equations are simple and straight forward and are still widely used and written as:

1- Uniformity Coefficient (UC)

$$
U C=100\left(\frac{\frac{1}{n} \sum\left|q_{i}-\bar{q}\right|}{\bar{q}}\right)
$$

2- Emission Uniformity (EU)

$$
E u=\left(1-1.27 \frac{C V_{M}}{\sqrt{n}}\right)\left(\frac{q_{l q}}{\bar{q}}\right) \times 100 \%
$$

where:

$q_{\mathrm{i}}$ is the discharge of emitter $\mathrm{i}, \bar{q}$ is the overall average of emitter discharges, $\mathrm{n}$ is the number of emitters, qlq is the average low-quarter emitter discharge, $\mathrm{S}$ is the 
standard deviation, $C V_{M}$ is the manufacturers' coefficient of variation for emitters $\left(C V_{M}=\frac{S}{q}\right)$.

The second method used in this study to determine the subsurface water uniformity was determined gravimetrically. The water uniformity through the soil profile was taken at three soil depths $(0,20$ and $40 \mathrm{~cm})$ and at different distances from emitter $(0,5,10,20$ and $25 \mathrm{~cm})$ in parallel and perpendicular directions to the dip line (Fig. 1(b)). The equation used to evaluate the subsurface uniformity of water redistribution below the soil surface was Christiansen's coefficient of uniformity $\left(\mathrm{Cu}_{\mathrm{s}}\right)$. This equation is the most widely and accepted criterion used to define uniformity (Zoldoske et al. [39]). The equation was written in the form:

$$
\begin{gathered}
C u_{\mathrm{S}}=100\left(1-\frac{\sum\left|\theta_{i}-\bar{\theta}\right|}{N \bar{\theta}}\right) \\
\bar{\theta}=\left|\sum_{i=1}^{N} \theta_{i}\right| / N
\end{gathered}
$$

where $\theta_{\mathrm{i}}$ is the measured gravimetric soil water content at depth $\mathrm{i}, \bar{\theta}$ is the mean gravimetric soil water content, and $\mathrm{N}$ is number of measured points.

The coefficient of each equation is influenced by different factors. The factors that affect the uniformity of water application from emitters are mainly discharge and pressure at emitter and the manufacturing variation in emitter discharge. While, the main factors that affect the uniformity of water redistribution in soil profile after irrigation are soil hydraulic properties and soil water diffusivity.

\section{Results and discussion}

The uniformity evaluation results of UC and EU for the water applied by the drip system were determined and presented in Fig. 2. Also, subsurface uniformity coefficients $\left(\mathrm{CU}_{\mathrm{s}}\right)$ at different depths and distances from emitter throughout soil profile of root zone after 24 hours from irrigation for the different irrigation scheduling methods were shown in Fig. 2. It can be observed that the average

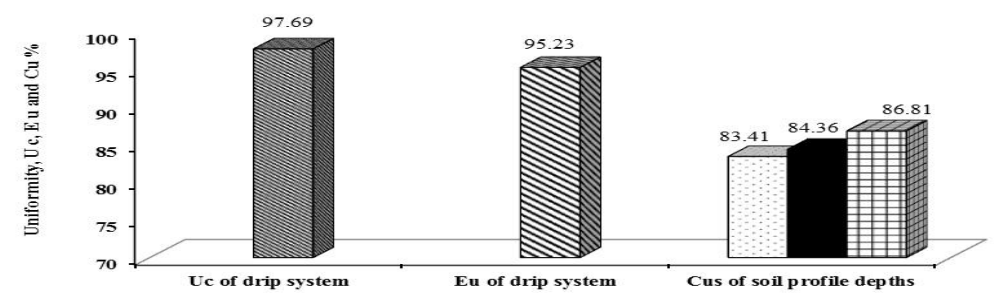

Figure 2: Uniformity coefficients of water applied (UC and EU) above soil surface and $\mathrm{Cu}_{\mathrm{s}}$ below soil surface for drip irrigation system using three irrigation scheduling methods 
values of UC and EU above soil surface were higher (97.69 and 98.60\%) than those average values of $\mathrm{CU}_{\mathrm{s}}$ below soil surface $(83.41 \%, 84.36 \%$ and $86.81 \%)$ through the soil profile in Parallel and perpendicular to the drip line for each irrigation scheduling method after 24 hours from irrigation. Therefore, it can be concluded that the water was distributed more uniformly from emitters above the soil and less uniformly below soil surface for all three scheduling techniques.

Also, a substantial amount of work has been done to measure and evaluate the subsurface water uniformity of drip irrigation system below the soil surface within the root zone at various distances from emitter and depths from zero depth on the ground to $40 \mathrm{~cm}$ depth below the soil ground for three different scheduling methods (Fig. 1(b)). The average values of $\mathrm{CU}_{\mathrm{s}}$ below the soil surface for three scheduling methods and three different depths and various distances from emitter in lateral (Parallel) and perpendicular direction to the drip line after 24 hours of irrigation were determined and compared to the values of UC of drip system as can be seen in Fig. 3.

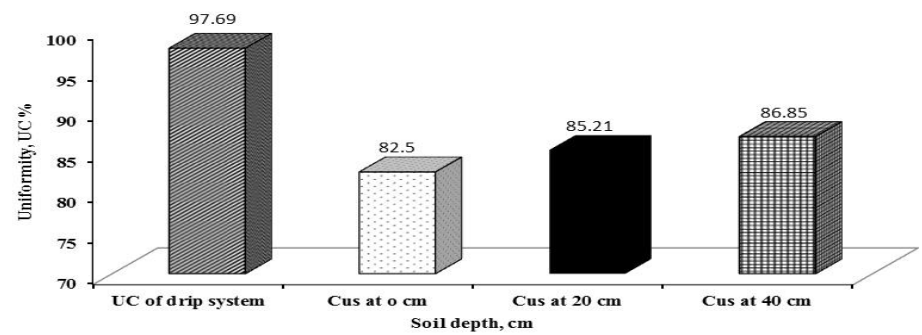

Figure 3: Average of uniformity coefficients of water applied from the drip system (UC) and the subsurface water uniformity $\left(\mathrm{Cu}_{\mathrm{s}}\right)$ at different depths within the soil root zone after 1 day of irrigation

From this figure, the values of UC of the drip system above soil surface were higher compared to the values of CUs below the soil surface (after $24 \mathrm{hrs}$. from irrigation) for all depths. This decrease in the uniformity within the root zone may be due to water movement within the soil matrix and a redistribution of soil moisture. Also, it was found that the values of $\mathrm{CU}_{\mathrm{s}}$ below soil surface were increased slightly with the increase of soil depth, and the highest mean value of uniformity occurred at $40 \mathrm{~cm}$ depth and the corresponding lowest value was obtained at $0 \mathrm{~cm}$ depth (Fig. 3).The average of the water uniformity coefficients below the soil surface at the three depths and various distance from emitter for the three scheduling techniques was $84.86 \%$ (Fig. 4) and this value of the water uniformity coefficient was above the acceptable uniformity level of design $(80 \%)$. These findings obtained in this study were in contradiction with the observation of Li and Kawano [31] and Al-Ghobari [34] who found that the uniformity coefficients values of the coefficient of uniformity below the soil surface were higher than those of the coefficient of uniformity above soil surface under conventional sprinkler and center pivot irrigation systems. This is may be 


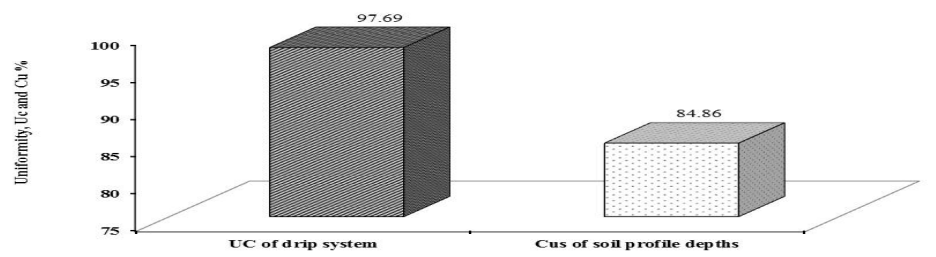

Figure 4: Average of coefficient uniformity of water applied above and below soil surface after 24 hours from irrigation for drip irrigation system.

due to the way of water application of drip and sprinkler systems and the water infiltration within the soil profile and the hydraulic gradients existing within the unevenly wetted soil which causing water movement laterally and perpendicularly within the soil profile to be less uniformly in the drip system resulting the water redistribution within soil profile to be less uniformly compared to sprinkler system.

In general, results indicated that the design and management of an irrigation system are not the only factors that influence water uniformity above and below soil surface for any irrigation system. Therefore, other factors should be taking into consideration, such as, the hydraulic gradients existing within the unevenly wetted soil which influence water movement laterally and perpendicularly within the root zone.

Many researchers have studied the function to represent the distribution of water application above soil surface from sprinkler and surface drip systems. However, the function to represent the distribution of water at different depth of soil profile after irrigation under DI has not been fully investigated. Measurement of uniformity for surface drip system above soil surface is straightforward but, is much more difficult for uniformity below the soil surface. However, given the difficulties inherent in the above mentioned work and above discussion concerning the prediction of redistribution water strongly suggests that an alternative approach to the subsurface evaluation of such irrigation systems is to relate the subsurface evaluation indexes to the surface evaluation indexes. Such a relationship describing the performance of drip system above soil surface in relation to the prediction of water redistribution below soil surface for DI to be useful index to the farmer and system designer. The results depicted in Fig. 5 is revealed the type of the relationship between the surface and subsurface uniformity coefficients (UC and CUs) of drip systems and which was found to be an exponential type with correlation coefficients $\left(\mathrm{R}^{2}=0.991\right)$, which has the following form:

$$
C U_{S}=20.918 e^{0.0178 U C}
$$

This equation can estimate the water redistribution uniformity coefficient below soil surface expected from drip irrigation system instead of the tedious work, which requires the field measurements of soil water contents. 


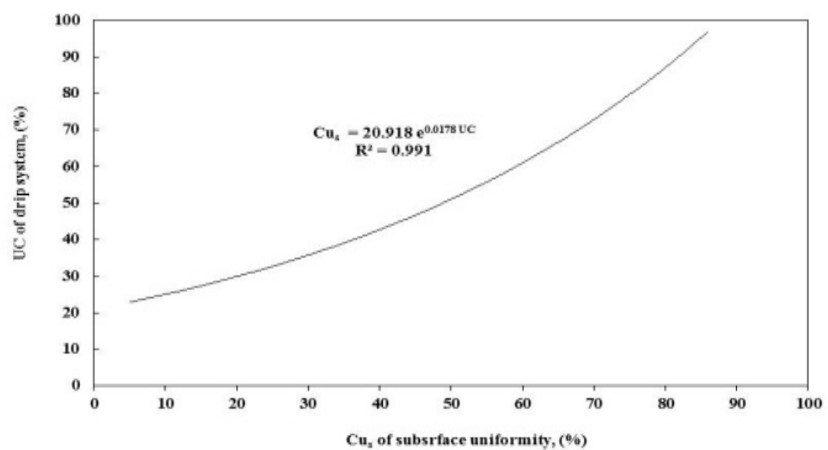

Figure 5: The relationship between the surface uniformity (UC) and subsurface uniformity $\left(\mathrm{CU}_{\mathrm{s}}\right)$ of drip system

\section{Conclusion}

Generally, it can be concluded that the uniformity of water application for the drip irrigation system at various depths and distances from emitter for all the three scheduling techniques were higher above soil surface compared to the uniformity below the soil surface after 24 hours from irrigation. Also, the subsurface coefficients of uniformity below the soil surface were varied and increased with the increase of soil depth from soil surface. The redistribution of water within the soil profile is a function of many irrigation scheduling methods and soil variables. Hence, In order to conserve water resources, close attention has to be paid to the performance of irrigation systems, and the results of the study conducted show that more attention needs to be paid to the subsurface distribution uniformity of an irrigation system.

An exponential relationship was found between the surface uniformity coefficient and the subsurface uniformity coefficient for drip irrigation system under arid condition. The derived equation may provide a useful guide to the potential performance of drip irrigation scheduling techniques with respect to redistribution of water under the soil surface, which should lead to savings of water resources in areas of limited supply. The study should also encourage drip surface irrigation system designers and users to reconsider previous concepts of the evaluation of drip surface irrigation systems above the soil surface.

\section{References}

[1] Acar B.; R. Topak; M. Direk 2010. Impacts of Pressurized Irrigation Technologies on Efficient Water Resources Uses in Semi-Arid Climate of Konya Basin of Turkey. Int. J. of Sustainable Water \& Environmental Systems. Volume 1, No. (1): pp. 1-4.

[2] Fabeiro, C.; de Santa Olalla F. Martin; de Juan, J. A. 2002. Production of muskmelon (Cucumis mela L.) under controlled deficit irrigation in a semi-arid climate, Agricultural Water Management, 54, pp. 93-105. 
[3] Hillel, D. 2008. 40 Years of Drip Irrigation. CSA. News. Vol. 53, No. 9, pp. 3-7.

[4] Locascio, J.S. 2005 Management of irrigation for vegetables: past, present, future, Hort Technology 15(3): pp. 482-485.

[5] Nautiyal, M., Grabow, G., Miller, G., and Huffman, R. L. 2010. Evaluation of two smart irrigation technologies in Cary, North Carolina. ASABE Annual International Meeting. David L. Lawrence Convention Center. Pittsburgh, Pennsylvania. June 20-June 23, 2010.

[6] Al-Omran, A. M., Sheta, A. S., Falatah, A. M., and Al-Harbi, A. R. 2005. Effect of drip irrigation on squash (Cucurbit Pepo) yield and water - use efficiency in sandy calcareous soils amended with clay deposits. J. Agric. Water Manag., 73 (1), pp. 43-55.

[7] Schwankl, L. J., Hanson, B. R. 2007. Surface drip irrigation. Micro irrigation for crop production, Eds. Lamm, F.R., Ayars, J.E., and Nakayama, F.S. Elsevier, pp. 431-472.

[8] Zotarelli, L., Scholberg, J. M., Dukes, M.D., Munoz-Carpena, R., Icerman, J., 2009. Tomato yield, biomass accumulation, root distribution and irrigation water use efficiency on a sandy soil, as affected by nitrogen rate and irrigation scheduling. Agricultural Water Management 96, pp. 23-34.

[9] Letey, J., Vaux, H. J. and Feinerman, N. 1984. Optimum crop water applications as affected by uniformity of water infiltration. Agron. J. 76: pp. 435-441.

[10] Solomon, K. H. 1984. Yield related interpretations of irrigation uniformity and efficiency measures. Irrig. Sci. (5) pp. 161-172.

[11] Letey, 1985. Irrigation uniformity as related to optimum crop productionAdditional research is needed. Irrig. Sci. (6) pp. 253-263.

[12] Solomon, K. H. 1990. Sprinkler irrigation uniformity. [Internet]. Centre for Irrigation Technology, California State University, Fresno, USA. Available from: <http://www.wateright.org/site/publications /900803.html>. [Accessed 29 June 2000].

[13] Solomon, K. H. 1983. Irrigation Uniformity and Yield Theory. Ph.D. thesis, Utah State University, Utah State University, Logan, USA.

[14] Clemmens A. J and Solomon K. H 1997 Estimation of global irrigation distribution uniformity. J. Irrig. Drain. Eng. 123 (6) pp. 454-461.

[15] Solomon K. H. 1990. Sprinkler irrigation uniformity. [Internet]. Centre for Irrigation Technology, California State University, Fresno, USA. Available from: <http://www.wateright.org/site/publications/900803 .html $>$. [Accessed 29 June 2000].

[16] Pereira L. S .1999. Higher performance through combined improvements in irrigation methods and scheduling: a discussion. Agric. Water Manage. 40 (2) pp. 153-169.

[17] Camp, C.R., Garrett, J.T., Sadler, E.J., and Busscher, W. J. 1993. Micro irrigation management for double-cropped vegetables in a humid area. Transactions of the ASAE 36(6): pp. 1639-1644. 
[18] Camp, C.R., Bauer, B.J., and Busscher, W.J. 1997. A comparison of uniformity measures for drip irrigation. Transactions of the ASAE 40(4): pp. 1013-1020.

[19] Nakayama, F. S. and D. A. Bucks. 1986. Trickle Irrigation for Crop Production - Design, Operation and Management, Developments in Agricultural Engineering 9. New York, N.Y.: Elsevier.

[20] Karmeli, D., Peri, G.; Todes, M 1985. Irrigation Systems: Design and operation. Oxford University Press. Cape Town, England. 1985. 187p.

[21] Wu, I.P., Barragan, J., and Bralts, V .F. 2007. Field performance and evaluation. Micro irrigation for crop production design, operation and management, Eds. Lamm, F.R., Ayars, J.E., and Nakayama, F.S. Elsevier, pp. 357-387.

[22] Wu, P., Gitlin, H.M., Solomon, K.H., and Saruwatari, C .A. 1986. Design principles-Trickle irrigation for crop production. Eds. Nakayama, F.S., and Bucks, D.A. Elsevier, pp. 53-92.

[23] Bralts, V.F., Wu, I.P., and Gitlin, H.M. 1981a. Manufacturing variation and drip irrigation uniformity. Transactions of the ASAE 24(1): pp. 113119.

[24] Bralts, V.F., Wu, I.P., and Gitlin, H.M. 1981b. Drip irrigation uniformity considering emitter plugging. Transactions of the ASAE 24(5): pp. 12341240.

[25] Burt, C.M., and Styles, S.W. 1994. Drip and micro-irrigation for tree, vine, and row crops. Irrigation Training and Research Centre. Cal Poly, San Luis Obispo, CA.

[26] Burt, C. M., Clemmens, A. J., Strelkoff, T. S., Solomon, K. H., Bliesner, R. D., Hardy, L. A., Howell, T. A., and Eisenhauer, D.E. 1997. Irrigation performance measures: efficiency and uniformity. J. of Irri. and Drain. Eng. 123(6): pp. 423-442.

[27] Burt, C. M. 2004. Rapid field evaluation of drip and micro spray distribution uniformity. Irrigation and drainage system 18: 275-297.

[28] Clark, G. A.; Rogers, D. H. and Martin, V. L. 2000. Measured and Simulated Uniformity on Low drift nozzle Sprinklers. ASAE, Paper No. 002021.

[29] Schwankl, L.J., Hanson, B.R. (2007) Surface drip irrigation. micro irrigation for crop production, Eds. Lamm, F.R., Ayars, J.E., and Nakayama, F.S. Elsevier, pp. 431-472.

[30] Davis, J. R 1963. "Efficiency factors in sprinkler system design," Sprinkler Irreg. Assoc. Open Tech. Conf. Proc. pp. 13-50.

[31] Li, J., Kawano, H., 1998. The areal distribution of soil moisture under sprinkler irrigation. Agric. Water Manage. 32, pp. 29-36.

[32] Hart, W. E. 1972. Subsurface distribution of non-uniformly applied surface water. Trans. ASAE, 15(4): pp. 656-661, 666.

[33] Thooyamani, K. P., D. I. Norum, and S. Dubetz. 1987. Application rates and uniformity under center-pivot sprinkler irrigation systems using spray nozzles. Can. Agric. Eng. 29: pp. 149-154. 
[34] Al-Ghobari, H. M. 2003. The areal distribution of applied water above and below soil surface under center pivot sprinkler irrigation system. Journal of the Saudi of Society of Agricultural Sciences. 2(2): pp. 207-220.

[35] ASAE Standards. Soil and water terminology. S256.1. ASAE Standards, Amer. Soc. Agric. Eng., St. Joseph, MI, 2007.

[36] Christiansen J. E. 1942. Irrigation by Sprinkling. California Agriculture Experiment Station Bulletin, No. 670. University of California, Berkley, USA.

[37] Karmeli, D. and J. Keller 1974. Trickle Irrigation Design. Rain Bird Sprinkler Manufacturing Corporation, Glendora, USA.

[38] Clemmens A. J and Solomon K. H 1997. Estimation of global irrigation distribution uniformity. J. Irrig. Drain. Eng. 123 (6) pp. 454-461.

[39] Zoldosk, D. F., Solomon K. H, Norum E. M. 1994. Uniformity measurements for turf grass: what's best? [Internet]. Center for Irrigation Technology, California State University, Fresno, USA. Available from: http://cati.csufresno.edu/cit/rese/94/941102.index.html. 